\title{
Euró - megoldás helyett maga a probléma?
}

\author{
Joseph E. Stiglitz: The Euro. How a Common Currency Threatens \\ the Future of Europe \\ W. W. Norton and Co., New York, 2016, 448 o.
}

2010 februárjára visszatekintve, amikor a görög államadósság kamatai újabb magasságokba szöktek, Joseph Stiglitz Nobel-díjas közgazdász - és akkoriban Papandreu görög miniszterelnök tanácsadója - az euróövezet hatóságait közös intervencióra sürgette, hogy a „spekulánsokat móresre tanítsák”. Stiglitz akként érvelt, hogy Görögországnak nincs szüksége sem adósmentő csomagra, sem a Nemzetközi Valutaalap beavatkozására. „Nyilvánvalóan nincs nemteljesítési kockázat a görög állampapírokon” - nyilatkozta.

Három hónappal később Görögország belement az első adósságelengedésbe, 120 milliárd dollárnak megfelelö összegben. Ezt megelőzően pedig mintegy 450 milliárd dolláros értékvesztést számoltak el az államkötvényeire.

Stiglitz legújabb könyvének - amely címe magyar fordításban: Az euró. Hogyan veszélyezteti a közös valuta Európa jövőjét - olvasásakor az a benyomásunk támad, hogy a szerzö tulajdonképpen mindig is elkerülhetetlennek tartotta a görög adósságválságot. Ahogy írja, az egymást követő kormányok meggondolatlan eladósodottságba sodorták az országot (15-17. o.). Az euróövezet pedig, amelybe Görögország 2001-ben nyert felvételt, „nem bocsátotta meg” az ilyetén pazarlást. A költségvetési fegyelem, amelyet elöírt, nem tartalmazta a válságkezelés esetét. Arra a feltételezésre épült, hogy az európai kormányok pénzügypolitikája biztosítja a piacról történő forrásbevonás állandóságát (34-62. o.).

Mindeközben még azokban az országokban is, amelyekben korábban a költségvetési fegyelem korlátok között tartotta a költségvetési hiányt (például Írország és Spanyolország), 2008-ban az ingatlanpiaci árzuhanást követően a nemfizető banki hitelek állománya megugrott, a munkanélküliségi ráták megemelkedtek. Stiglitz egyértelmű a kiváltó okok tekintetében: tudniillik Németország (a poroszos szigor) és az euró (113-118. o.).

Az igazság - ahogy Oscar Wilde-tól szokták idézni - az ember utolsó hangulata (Truth is one’s latest mood). Márpedig Stiglitz hangvétele erősen különbözik attól, amilyen 2010-ben volt, amikor Görögország tanácsadójaként nyilatkozott. Akkor az ország érdeke a spekulánsok elleni fellépést sürgette. Mára nyilvánvalóvá vált, hogy a görög 
adósságválság elkerülhetetlen volt. Európa vajúdása, ahogy fogalmaz, mindenekelőtt egy háttérben meghúzódó ok, a közös pénz létrehozásának tudható be.

Stiglitznek ez a 19. könyve, amióta 2000-ben lemondott a világbanki tisztségéről. Ebben áttekinti a válság elhúzódását, és leírja azt a jelenséget, amelyben az euró szerepét szerinte félreértelmezték: a jelenlegi gazdaságpolitikai stratégiák csak rontanak a helyzeten, illetve erre megoldásként egy, a válságból kivezető utat vázol fel. De mindenekelőtt a könyv egy könyörtelen vádirat az euróövezet müködését felügyelö gazdaságirányítókkal szemben, akiket azzal vádol, hogy a haladó gazdaságstratégiákkal szemben minden lehetséges bünt elkövettek. Ebben a tekintetben a könyv egybecseng Stiglitz korábbi, a globalizáció és az egyenlőtlenség témájában írt müveivel csak éppen most az euró minden rossz forrása.

A szerző például egyrészt tevőleges bünöket említ - ide sorolja a költségvetési deficites tagállamok számára nyújtott gazdaságpolitikai iránymutatásokat, vagy a munkaerőpiac mobilitásáért tett erőfeszítéseket (8. fejezet, 214-223. o.). Az előbbi lépések felerősítették az egyenlőtlenségeket, és ez visszavetette a térség gazdasági növekedését. A szerző ilyetén állásfoglalását Paul Krugman, a szintén Nobel-díjas közgazdász feltehetően nem osztja...

Másrészt voltak mulasztási bünök - olyan gazdaságpolitikai ajánlások, melyek elöremutatóak lettek volna, amennyiben követik ezeket (223-230. o.). Például az euróövezet „válságban lévő” országai esetében elmaradtak „a klímaváltozásra adekvát válaszokat adó reformlépések". Az északi államok zöldberuházásai - a mérséklődő energiaköltségeken keresztül - ugyanis javíthatták volna a folyó fizetési mérleg egyenlegét. Nem mellékes - és az európai ártámogatási rendszer is ezt igazolja -, hogy az üvegházhatást okozó gázok kibocsátásának csökkentésére irányuló gyakorlati lépések éppen (a szerző állításával szemben) az energiaköltségek nemhogy mérséklődéséhez, de jelentős növekedéséhez vezetnek.

Stiglitz a bünösöket olyan jelzőkkel illeti, mint „,neoliberális”, „piaci fundamentalista” vagy árupiaci spekuláns (gold bug) (109. o.). Néhányan közülük úgymond elismerték bünösségüket; a könyv természetesen nem említ konkrét neveket. A tervük része volt, hogy a munkanélküliség növekedjen a „válságban lévö” országokban (110-118. o.). A Görögország hitelezőiből álló „trojka” (az Európai Bizottság, az Európai Központi Bank és a Nemzetközi Valutaalap) ,úgy vélte, hosszú távon ez fogja az euró végét jelenteni” (155-157. o.). A szerző a hivatali visszaélés gyanúját is elhinti a devizatartalékok menedzselése kapcsán, utalva arra, hogy Mario Draghi, az Európai Központi Bank elnöke korábban évekig a Goldman Sachsnál dolgozott (158. o.).

Nem sokkal finomabban fogalmazza meg véleményét Jean-Claude Junckerről, az Európai Bizottság elnökéröl, akit a „luxemburgi vállalatiadó-elkerülési programok büszke kiötlőjének” hív (228. o.), vagy épp Angela Merkelröl, akit deficitfetisiszta sváb háziasszonyként jellemez (186. o.). A szerző azonban a strikt német álláspont ostorozása mellett elfelejti megemlíteni például Franciaország jelentékeny szerepét a válságkezelés módjában vagy épp Németország ragaszkodását a görög adósságelengedéshez 2012-ben.

A könyv maga - némely fejezeteiben - még a megértő olvasó számára is unalmasnak tünhet. De vannak szórakoztató részek is; mint például a 12. fejezet, amelyben Stiglitz 
azt javasolja Európának, hogy fogadja el a nézetkülönbségeket. Ahogy írja, „némely társadalmak inkább a stabilitást és a szociális biztonságot részesítik előnyben, többet fordítanak közoktatásra és egészségügyre; míg mások inkább a meglévő társadalmi egyenlőtlenségeket kívánják konzerválni” (317. o.). Az olvasóban mindenesetre kétségek támadhatnak afelöl, hogy vannak, akik jóléti társadalmakban szeretnének élni annak minden előnyével, míg másvalakik nem nézik jó szemmel a társadalmi haladást.

De mindezek ellenére Stiglitz legtöbb neheztelő kijelentése nem kerüli meg a lényeget. Így például a 12. fejezetben azt is írja, hogy a gazdaság kibocsátásának csökkenése közepette óriási gazdasági, társadalmi és politikai hiba volt Németország ragaszkodása a görög megszorításokhoz és adóemelésekhez azért, hogy az új kölcsönöket kapjon a korábbi adósságok kifizetésére (312. o.). Nem jó ötlet csődben levő országok további eladósítása - nem müködött a világháborúk után, és nem müködik most sem. Németországnak ezt mindenképpen tudnia kellett volna.

Mióta az önérdek ilyen mértékben kifejezésre jut, a mentőcsomag kifejezés nem rokon értelmủ a segéllyel. 2010 márciusában, az első görög mentőcsomag bejelentése előtt két hónappal, az európai bankok mérlegében 149 milliárd euró görög adósság volt. Ebböl 62 milliárd a francia, míg 37 milliárd a német bankokéban. Így a mentöcsomagot tető alá hozó trojka 120 milliárdos kölcsöne nagyrészt az európai bankok mentőcsomagja volt (202. o.). Kötvények kibocsátásával ezután a francia pénzintézetek csaknem teljesen megszabadulhattak a görög kintlévőségeiktől.

A szerző szerint bármennyire is tragikus a görög válságkezelés, Európa jelenlegi problémáinak tekintetében az eredendő bün maga az euró. A negyedik fejezetben Stiglitz azt írja: „Görögország, ha az euróövezeten kívül marad, nem adósodik el német devizában”, méghozzá azért, mert tudatában lett volna ennek kockázataival (115-118. o.). Ez nem feltétlenül igaz. A fejlődő országok régóta komoly, dollárban denominált adósságot halmoztak fel, ennek az államra vagy a belföldi bankokra gyakorolt kockázatai ellenére. Ezenfelül 2000-ben, egy évvel Görögország euróövezethez való csatlakozása elött, a görög adósság 79 százaléka euróban állt fenn, míg drachmában csupán 8 százaléka. Az adósságválság tehát bekövetkezett volna függetlenül attól, hogy az ország a közös pénzt bevezeti vagy sem.

Komoly érvek szólnak amellett, hogy megkérdőjelezzük Stiglitz professzor euróövezettel szembeni erős szkepticizmusát. Vajon az Európai Központi Bank inflációs célkitűzése okozza a túlzottan szigorú monetáris politikát (145-150. o.)? A központi bank mandátuma valóban elsődlegesen az inflációs célkövetés, melyben a cél az infláció 2 százalék alatti, de azt megközelítő értéke. Ez a mandátum azonban lehetővé teszi a valutaközösség egyéb gazdasági céljainak támogatását is, egészen addig, amíg azok az árstabilitás fenntartását nem veszélyeztetik. Márpedig a harmonizált fogyasztói árindex az utóbbi három és fél évben nem érte el a 2 százalékot, és jelenleg a nullához közelít.

A 6. fejezetben Stiglitz két dolgot mond egyszerre. Az EKB-t egyik részről azért illeti kemény kritikával, mivel az „a mennyiségi lazítást amerikai és a japán jegybanki eszköztárba való felvétele után sem hajlandó elkezdeni” (151-153. o.). Máshol pedig úgy érvel, „a mennyiségi lazítás legfontosabb hatása az egyenlőtlenségek növekedésének elősegítése", ami végső soron gátolja a növekedést (153-154., 165-166. o.). 
Stiglitz állítása, hogy egy monetáris unió (mint amilyen az euróövezet) sikerességéhez politikai, költségvetési és bankunióra van szükség (321-323. o.). Amerikában egy dollár mondjuk egy arkansasi bankban éppolyan értékes, mint egy New York-i bankban, mivel mindegyik visszafizetését a szövetségi betétbiztosítás garantálja. Egy euró egy görög bankban ezzel szemben biztosan kevesebbet ér, mint egy németben (30. o.). A görög bank és a görög állam biztosítása kevesebbet ér, mivel azok nagyobb valószínüséggel mennek csődbe. A görög euró könnyebben váltható át drachmára, mint német euróra - ahogy az amerikai dollárt váltották pesóra Argentínában 2001-ben.

Érdemes lehet felidézni, hogy Ecuador és El Salvador egyoldalúan vezette be az amerikai dollárt az ország egyedüli fizetőeszközének, ráadásul éppen akkor, amikor Görögország csatlakozott az euróövezethez. Ezen országok gazdasága azóta is biztonságban van, és ehhez nem volt szükség külső segítségre, sem pedig politikai, fiskális vagy épp bankunióra. A valutaközösségek akkor maradhatnak fenn, ha a benne részt vevők nem bízhatnak mentőcsomagban. A probléma az, hogy az euróövezetben ez nem teljesült.

Az euró mellett a másik „bünös” Németország, amely saját érdekei szerint alakította ki a játékszabályokat az euróövezetben, és gazdasági súlyát felhasználva határozta meg a gazdasági mentőcsomagok feltételrendszerét (7. fejezet, 177-213. o.). Ez és az euró fix árfolyama az oka annak, hogy az euróövezetben ahelyett, hogy a céloknak megfelelően az egyes tagországok között erősödött volna a konvergencia, az egyenlőtlenségek nőttek. Stiglitz példának hozza, hogy míg 2007-ben a német GDP a görögnek 10,4-szerese volt, addig 2015-re 15-szeresére növekedett (92. o.). A megoldás szerinte az euró árfolyamának kiigazítása lehetne.

A tapasztalat azonban azt mutatja, hogy önmagában a kiigazítható árfolyam nem elegendő. Vegyük például Izlandot, ahol a devizaárfolyam okozott hatalmas kereskedelmi deficitet a válság előtt, vagy épp Svájcot, ahol pedig jelentős szufficit halmozódott fel. Mi több, az euró sem okoz természetszerüen válságot, ahogy azt a válság zürzavaros időszakában, 2009-ben bevezetett szlovák euró mutatja.

Az árfolyam-kiigazítások, a lebegó árfolyam mellett Stiglitz szerint lehetőség lenne az euró születése óta létező hibák kijavítására, amellyel elkerülhetővé válna a valutaövezet felbomlása. Ehhez a tagországok között több szolidaritásra, a terhek és a kockázatok jobb felosztására lenne szükség, aminek alapfeltétele a felek közti bizalom megteremtése (244-255. o.). Az európrojekt hosszú távú fenntartásához pedig Stiglitz szerint meg kell valósítani a politikai, fiskális és bankuniót (241-242. o.).

Stiglitz több könyvéhez hasonlóan itt is kitér arra, hogy a további problémák oka, hogy a nyugati társadalmakban a gazdagok (vagyis „az elit”) és a szegények közti szakadék egyre növekszik (225-228. o.). Az egyenlőtlenségről nagyjából osztja francia kollégája, Thomas Piketty véleményét, aki 2014-ben is azt írta, hogy Amerika többé már nem a korlátlan lehetőségek hazája.

A 9. fejezet tanulsága szerint a fö probléma az, hogy az olyan aggregált makrogazdasági mutatók, mint a GDP vagy a munkanélküliség, elfedhetnek fontos társadalmi jelenségeket (256-257., 262-263. o.). Európa válság sújtotta államaiban is csökken ugyan a munkanélküliség, és ma már Görögország GDP-je is növekvő pályára állt, 
az átlagos mutatók javulása az országon belüli egyenlőtlenségek növekedésével járt együtt (263-267. o.). A fiatalkorúak magas munkanélkülisége, a perifériára szorult társadalmi rétegek arányának emelkedése, a döntési folyamatok áttekinthetetlenné válása azt az érzetet keltheti a globalizáció veszteseiben, hogy az ő véleményük (és persze: az ő érdekük) másodlagos.

Tény és való azonban, hogy a növekvő egyenlötlenségek miatt Európának lépnie kell. Az aggodalmakat növelheti, hogy az elittel szembeni társadalmi bizalmatlanság miatt a populisták nemcsak állnak a kapuk elött, hanem sok esetben át is törték azt (lásd brexit), 2017-ben pedig az euróövezet két legnagyobb gazdaságában tartanak választásokat, ahol szintén politikaváltás várható. A kérdés tehát az, hogy megbukott-e a közös pénz projektje, és ha igen, akkor hogyan tovább.

Összességében nehéz cáfolni Stiglitznek azt a következtetését, hogy „az euróövezet egésze rosszul teljesít" (322. o.). A lecke - ahogy azt ő is elismeri - az, hogy a piacok komplex intézmények, és hogy komplexitásuk megértése nélkül egyszerü javítgatásuk katasztrofális következményekhez vezethet. Így ha Stiglitz a közjó érdekében irányítani tudná a pénz teremtését és elosztását, a világ egy sokkal szebb hely lehetne. De addig is vigasztaljon minket a tudat, hogy ír még néhány könyvet azért, hogy emlékeztessen minket erre!

Sági Judit

Sági Judit, a Budapesti Gazdasági Egyetem Pénzügyi és Számviteli Karának docense. 